\title{
Protecting innovation from unfair practices
}

\section{Vesala, Juha Tuomas}

Edward Edgar

2018

Vesala , J T 2018, Protecting innovation from unfair practices . in P Nihoul \& P Van Cleynenbreugel (eds), The Roles of Innovation in Competition Law Analysis ., 4 , ASCOLA

Competition Law series , Edward Edgar , pp. 50-77 . https://doi.org/10.4337/9781788972444.00012

http://hdl.handle.net/10138/309594

https://doi.org/10.4337/9781788972444.00012

unspecified

acceptedVersion

Downloaded from Helda, University of Helsinki institutional repository.

This is an electronic reprint of the original article.

This reprint may differ from the original in pagination and typographic detail.

Please cite the original version. 
ASCOLA 2016 - working paper, please ask before citing

Protecting innovation from unfair practices

Juha Vesala, Post-doctoral researcher, LL.D.

University of Helsinki, Faculty of Law

\section{Introduction}

A considerable share of unilateral (single-firm) conduct, in which the European Commission ("EC") and US Federal Trade Commission ("FTC") have recently intervened in order to address concerns about innovation, has involved concerns other than anti-competitive foreclosure prohibited as exclusionary conduct (e.g. EU exclusionary abuses or US monopolization). Instead, in these cases, alleged anticompetitive effects have been based on conduct threatening other firms' rewards for innovation and incentives to innovate through other mechanisms, such as free-riding or opportunism. To address these concerns, the EC and FTC have relied on their powers that also extend to certain unfair practices (e.g. EU exploitative abuses or US standalone unfair methods of competition).

This article examines theories of non-exclusionary innovation harm that can be gleaned from recent interventions and ongoing investigations by the EC and FTC. Examples of such harm to innovation can be found in cases dealing with the exercise of standard-essential patents ("SEP") and aspects of Google specialized search services. In essence, the concern in these cases is that the conduct threatens other firms' incentives to innovate by depriving them of appropriate rewards for innovation. Concerns based on insufficient rewards harming innovation are unusual for antitrust, but could amount to anti-competitive harm when harm to innovation results from the exercise of market power. However, anti-competitive effects of that kind are theoretically and empirically uncertain, and the practices examined have significant inherent pro-competitive aspects. To avoid deterring practices that overall promote innovation and consumer welfare, anti-competitive effects on innovation should be 
ASCOLA 2016 - working paper, please ask before citing

established as likely and pro-competitive aspects of conduct as either disproportionate or insufficient in magnitude.

The article proceeds as follows. First, it examines reliance by the EC and the FTC on theories of harm that go beyond anti-competitive foreclosure and/or more conventional antitrust standards for exclusionary conduct (Section 2). Second, cases dealing with SEPs and Google specialized search services in the EU and US dealing with these alleged or suspected anti-competitive effects on innovation are examined and aspects of non-exclusionary theories of innovation harm raised in them are discussed (Section 3). Third, the paper considers whether and under what conditions these unconventional theories of harm to innovation could justify antitrust liability (Section 4). Lastly, conclusions are presented (Section 5).

\section{Use of unfairness powers in the EU and US in antitrust enforcers' interventions in unilateral practices allegedly threatening innovation}

\subsection{US and EU antitrust law powers to address unilateral practices beyond exclusionary conduct}

Antitrust law in the US and EU empowers public enforcers to remedy anti-competitive single-firm conduct. ${ }^{1}$ Article 102 TFEU, ${ }^{2}$ which the EC can enforce, covers abuse of a dominant position, and Section 5 of the FTC Act, ${ }^{3}$ which the FTC can enforce,

\footnotetext{
${ }^{1}$ In this article, the focus is on public enforcement of antitrust law by the EC and the FTC, so that private reliance on unfairness powers is beyond the scope of the paper. Nevertheless, it can be mentioned that in the EU, the relevant unfairness powers under Art. 102 TFEU can also be relied on by private litigants, as indeed is regularly the case. By contrast, in the US, only the FTC can enforce $\S 5$ FTC Act, whereas private litigants or other public antitrust enforcers cannot base their claims directly on it.

${ }^{2}$ Art. 102 of the Treaty on the Functioning of the European Union ("TFEU") ("Any abuse by one or more undertakings of a dominant position within the internal market or in a substantial part of it shall be prohibited as incompatible with the internal market in so far as it may affect trade between Member States.")

315 U.S.C. $\S 45$ Sec. (a)(1) ("Unfair methods of competition in or affecting commerce, and unfair or deceptive acts or practices in or affecting commerce, are hereby declared
} 
ASCOLA 2016 - working paper, please ask before citing

prohibits unfair methods of competition. Both prohibitions cover exclusionary conduct expected to involve anti-competitive effects based on exclusion of rivals from the market (anti-competitive foreclosure) as well as certain other unilateral practices that produce anti-competitive effects through other mechanisms. For instance, the EU concept of abuse also covers the imposition of excessively high prices or unreasonable terms on customers (exploitative abuses) that do not involve foreclosure from the market. ${ }^{4}$ Moreover, the US concept of unfair methods of competition extends beyond exclusionary conduct under Section 2 of the Sherman Act (monopolization and attempted monopolization). ${ }^{5}$ The EC and FTC can thus address unilateral conduct even when it does not involve anti-competitive foreclosure or is not unlawful under antitrust

unlawful."). This paper focuses solely on unfair methods of competition, thus leaving unfair and deceptive practices (raised in several of the FTC cases discussed) outside its scope.

${ }^{4}$ See e.g. Case 27/76 United Brands v Commission [1978] ECR 207; Case C-52/07 Kanal 5 Ltd and TV 4 AB v Föreningen Svenska Tonsättares Internationella Musikbyrå (STIM) upa. [2008] EU:C:2008:703; Case 127/73 Belgische Radio en Televisie and société belge des auteurs, compositeurs et éditeurs v SV SABAM and NV Fonior [1974] EU:C:1974:25.

${ }^{5}$ The US Supreme Court has recognized the broad potential reach of Section 5 FTC Act that goes beyond Sherman Act $\S 1$ and $\S 2$ violations. See e.g. FTC v. Indiana Federation of Dentists, 476 U.S. 447, 454 (1986); FTC v. Sperry \& Hutchinson Co., 405 U.S 233, 244 (1972). However, US Courts of Appeal have required that the FTC employs standards that allow firms to distinguish unlawful conduct from legitimate practices in a predictable manner. See e.g. Official Airline Guides, Inc v. FTC, 630 F.2d 920, 927 (2d Cir. 1980); Boise Cascade Corp. v. FTC, 637 F2d 573, 582 (9th Cir 1980); E.I. du Pont de Nemours \& Co. v. FTC, 729 F.2d 128, 139 (2d Cir. 1984). See for FTC view of the standards and reliance on standalone application beyond the scope of the Sherman and Clayton Acts, FTC, "Statement of Enforcement Principles Regarding 'Unfair Methods of Competition' Under Section 5 of the Federal Trade Commission Act” (Commission policy statement), Federal Register Vol. 80, No. 182, p. 57056 [2015]. For an example of an alleged stand-alone violation involving no exclusion but failure to uphold a licensing commitment, see In the matter of Negotiated Data Solutions LLC. (File No. 051 0094) FTC, Complaint of 23 September 2008, Docket No. C4234. Moreover, even the Sherman Act covers certain exploitative aspects. Harry First, "Exploitative Abuses of Intellectual Property Rights" New York University Law and Economics Working Papers (2016), Paper 446. 
ASCOLA 2016 - working paper, please ask before citing

standards concerning exclusionary conduct (e.g. exclusionary abuses or monopolization).

2.2. Exercise of unfairness powers to protect innovation: interventions in unilateral practices by the EC and the FTC

In the area of single-firm conduct, the focus of both EU and US enforcers is on practices that anti-competitively foreclose rivals from the market. ${ }^{6}$ Nevertheless, a significant share of cases where the EC and FTC have intervened in unilateral practices (cases that were closed either by a decision finding infringement ${ }^{7}$, with a

\footnotetext{
${ }^{6}$ See e.g. European Commission, "Guidance on the Commission's enforcement priorities in applying Article 82 of the EC Treaty to abusive exclusionary conduct by dominant undertakings" [2009] OJ C 45/7, paras 6-7. During approximately the past 10 years (20052015), the EC and FTC have indeed mostly focused on exclusionary conduct (e.g. unlawful as exclusionary abuses in the EU or monopolization in the US). For EC cases that can be characterized as involving exclusionary abuses or other abuses based on foreclosure concerns, see e.g. Intel (Case COMP/C-3/37990) EC, decision D(2009) 3726 final of 13 May 2009; Astra Zeneca (Case COMP/A.37507/F3) EC, decision 2006/857/EC of 15 June 2005 (C(2005) 1757); Microsoft (Case COMP/C-3/37792) EC, decision C(2004) 900 final of 24 March 2004; Microsoft (tying) (Case COMP/C-3/39530) EC, decision of 16 December 2009 (C(2009) 10033); Prokent/Tomra (Case COMP/E-1/38113) EC, decision C(2006)734 of 29 March 2006; Rio Tinto Alcan (Case COMP/39230) EC, decision C(2012) 9439 final of 20 December 2012; Perindopril (Servier) (Case AT.39612), EC, decision C(2014) 4955 final of 9 July 2014. European Commission, "Ten Years of Antitrust Enforcement under Regulation 1/2003: Achievements and Future Perspectives" (COM/2014/453/FINAL, 9 July 2014) (between May 2004-December 2013, 84 \% of Art 102 TFEU cases involved exclusionary abuses and $16 \%$ exploitative abuses).

${ }^{7}$ See e.g. Motorola - Enforcement of GPRS standard essential patents (Case AT.39985) EC, decision C(2014) 2892 final of 29 April 2014 (finding infringement but not imposing fines).
} 
ASCOLA 2016 - working paper, please ask before citing

binding settlement ${ }^{8}$ or upon the firm altering its conduct ${ }^{9}$ ) involves other than foreclosure concerns or conduct prohibited as exclusionary conduct.

Out of the EC and FTC interventions in which some kind of anti-competitive harm to innovation was mentioned in the case documents (e.g. decision or complaint), a considerable share involves explicit allegations of unfair conduct (exploitative abuses under Article 102 (a) TFEU in the EU or stand-alone violations of the $\S 5$ FTC Act). ${ }^{10}$ Some of these unfairness allegations are raised independently, that is, without claims of exclusionary conduct or foreclosure concerns. ${ }^{11}$ However, some of these cases seem to be "gap" cases where exclusionary concerns may have been involved, but were remedied under unfairness powers. ${ }^{12}$

Further, in various cases, foreclosure and non-foreclosure theories of harm were cited either as parallel or alternative concerns. For instance, in EC and FTC cases

\footnotetext{
${ }^{8}$ Indeed, most of the unilateral cases examined below were closed with a commitment decision (EC) or a consent order (FTC).

${ }^{9}$ See e.g. EC, “Antitrust: Commission welcomes improved market entry for lung disease treatments" (Press release IP/11/842, 6 July 2011); FTC, "Statement of the Federal Trade Commission Regarding Google's Search Practices In the Matter of Google Inc. File No. 1110163" (Statement, 3 January 2013), available at
}

<https://www.ftc.gov/system/files/documents/public_statements/295971/130103googlesearch stmtofcomm.pdf> accessed 17 June 2016.

${ }^{10}$ For FTC cases involving stand-alone $§ 5$ FTC Act violations, see e.g. In the matter of Motorola Mobility LLC, and Google Inc. (File No. 121 0120) FTC, Docket No. C-4410; In the matter of Bosch (Robert Bosch GmbH) (File No. 121 0081) FTC, Docket No. C-4377; In the matter of Negotiated Data Solutions LLC. (File No. 051 0094) FTC, Docket No. C-4234. For EC decisions based on exploitative abuses, see e.g. Rambus (Case COMP/38636) EC, decision of 9 December 2009; Standard \& Poor's (Case COMP/39592) EC, decision C(2011) 8209 final of 15 November 2011.

${ }^{11}$ See e.g. In the matter of Negotiated Data Solutions LLC. (File No. 051 0094) FTC, Docket No. C-4234; Rambus (Case COMP/38636) EC, decision of 9 December 2009.

${ }^{12}$ See e.g. Rambus (Case COMP/38636) EC, decision of 9 December 2009. In this case, royalties were alleged as excessive in view of patent ambush, which itself potentially could have been addressed as an exclusionary abuse had Rambus been dominant at that time as required under Art. 102 TFEU. 
ASCOLA 2016 - working paper, please ask before citing

concerning SEPs, several of the enumerated competition concerns relate to the effects of higher royalties or other disadvantageous terms of licensing on consumers, innovation and standardization, either in addition to or as alternatives to effects based on exclusion of standard-compliant products from the market (see Section 3.1 for details). ${ }^{13}$

In some cases, the legal characterization of antitrust infringement is not explicit or clear (whether an exclusionary or some other kind of antitrust violation is invoked), but the conduct challenged, anti-competitive effects mentioned, remedies sought or commitments offered suggest competition concerns that are not confined to anticompetitive foreclosure. For instance, as explained below (Section 3.2), some of the concerns in EC and FTC Google investigations extend beyond anti-competitive foreclosure of rivals that either does not constitute established forms of exclusionary conduct (e.g. exclusionary abuse or monopolization) or seems to extend beyond foreclosure concerns altogether. ${ }^{14}$

${ }^{13}$ For EC cases involving both the risk of exclusion of products from the market and other
kinds of competition concern (e.g. imposition of disadvantageous licensing terms), see e.g. Motorola - Enforcement of GPRS standard essential patents (Case AT.39985) EC, decision C(2014) 2892 final of 29 April 2014; Samsung - Enforcement of UMTS standard essential patents (AT.39939) EC, decision C(2014) 2891 final of 29 April 2014. For FTC cases involving both foreclosure and other kinds of concern (stand-alone $§ 5$ FTC Act unfair methods of competition of both an exclusionary and non-exclusionary nature), see e.g. In the matter of Motorola Mobility LLC, and Google Inc. (File No. 121 0120) FTC, Complaint of 24 July 2013, at 38; In the matter of Rambus Inc. (File No. 011 0017) FTC, Complaint of 18 June 2002 Docket No. 9302 (claiming alternatively monopolization or unfair methods of competition - questioned by the US Court of Appeals for the District of Columbia in Rambus v. FTC, 522 F.3d 456).

${ }^{14}$ Examples can also be found in other types of case. For instance, the FTC's concerns regarding Intel's licensing practices seem to have features that appear to extend to aspects not limited to foreclosure but ensuring "fair" opportunities for firms that are not confined to concerns about anti-competitive foreclosure of actual or potential competitors. See e.g. In the matter of Intel Corporation (1999) (File No. 9510028 FTC, Complaint of 8 June 1998, Docket No. 9288, para. 15 (“A natural and probable effect of Intel's conduct is to diminish the incentives of those three Intel customers -- as well as other firms that are Intel customers or otherwise commercially dependent upon Intel -- to develop new innovations relating to 
ASCOLA 2016 - working paper, please ask before citing

\section{Theories of non-exclusionary innovation harm in cases concerning standards-essential patents and Google specialized search services}

In a sizeable share of their enforcement activities seeking to protect and promote innovation, as noted above, the EC and FTC have employed theories of harm and infringement that go beyond established legal standards for exclusionary conduct and concerns about anti-competitive foreclosure. Below, these aspects of EC and FTC cases dealing with the enforcement and licensing of patents essential to industry standards and Google specialized search services are discussed.

\subsection{Licensing and enforcement of standard-essential patents}

The EC and FTC have both been active in the field of enforcement and licensing practices of standard-essential patent holders. Interventions by the European Commission and by the US FTC in practices are not solely based on foreclosure from product or technology markets, but also involve concerns about exploitation of hold-up or market power otherwise threatening innovation. Moreover, the latter concerns may be more generally applicable, as argued below.

\subsubsection{Potential exclusionary effects of enjoining products infringing SEPs}

Seeking and obtaining injunctive relief for infringement of an SEP can result in exclusion from the market of infringing standard-compliant products, but does not necessarily result in anti-competitive foreclosure. First, although an SEP holder may

microprocessor technology. Intel's coercive business tactics effectively undermine the patent rights of such firms and reduce their incentives to develop new technologies relating to microprocessors."). 
ASCOLA 2016 - working paper, please ask before citing

have the ability to exclude an infringing product from the market (if infringement is established and an injunction granted), an SEP holder may lack the incentive to exclude when it is better off concluding a licensing agreement. ${ }^{15}$ Therefore, exclusion of an infringer from the product market may be avoided altogether or be short lived if a licensing agreement is concluded once an injunction is granted. Second, the effects of enjoining the sales of a particular infringing product may have modest market-wide effects on any parameter of competition (e.g. price or quality) and ultimately on consumer welfare if other firms are offering competing alternatives. ${ }^{16}$ Third, the ability of an SEP holder to obtain an injunction is limited to begin with. It depends, in particular, on whether a court finds a patent infringement and grants an injunction.

\subsubsection{Threats to innovation of exploiting market and hold-up power}

While recourse to injunctive relief by an SEP holder can result in anti-competitive foreclosure, as noted above, it may also be avoided or remain limited in magnitude.

${ }^{15}$ See e.g. Google/Motorola Mobility (COMP/M.6381) EC, decision C(2012) 1068 of 13 February 2012 (examining concerns whether following the transaction there would be the ability and incentive to exclude rivals with SEPs).

${ }^{16}$ Nevertheless, depriving consumers of a specific product could be interpreted as such an effect of excluding that particular product and thus reducing consumer choice. See e.g. Motorola - Enforcement of GPRS standard essential patents (Case AT.39985) EC, decision C(2014) 2892 final of 29 April 2014, para. 312 ("By seeking and enforcing an injunction, a SEP holder may be able to exclude even the most innovative standard-compliant products from the market as, by definition, the patented technology cannot be worked around. In turn, the elimination of competing products from the market may limit consumer choice and partially eliminate downstream competition"); In the matter of Motorola Mobility LLC, and Google Inc. (File No. 121 0120) FTC, Complaint of 24 July 2013, Docket No. C-4410, para. 28 (a) (listing among alleged anti-competitive effects "Depriving end consumers of competing products that comply with the Relevant Technology Standards, including mobile phones, tablet computers, and "smart" devices providing internet access such as gaming systems, laptops, and set-top boxes"). 
ASCOLA 2016 - working paper, please ask before citing

Regardless of whether or not such foreclosure concerns are likely, concerns based on exploitation of market and/or hold-up power can nonetheless arise.

Indeed, the EC and FTC have recognized and cite such non-exclusionary concerns in their interventions in SEP holders' conduct. First, they note in the cases that exploitation of market and hold-up power may harm consumer welfare to the extent that royalties are raised and higher licensing costs are passed on to customers of standard-compliant products. ${ }^{17}$ Those higher licensing costs may also dull competition among manufacturers of standard-compliant products. ${ }^{18}$

Second, sought or attained higher licensing fees or other disadvantageous terms of licensing that amount to exploitation of hold-up or market power have been recognized by the FTC and EC as potentially threatening innovation. In principle, disadvantageous licensing terms could threaten the incentives of producers of standard-compliant products, whose incentives to innovate in those products may be reduced if SEP holders demand excessive licensing fees. SEP holder claims for excessive rewards can thus threaten the incentives of other innovators by denying the latter's rewards for value created by their innovations (e.g. innovations regarding

${ }^{17}$ See e.g. In the matter of Motorola Mobility LLC, and Google Inc. (File No. 121 0120) FTC, Complaint of 24 July 2013, Docket No. C-4410, para. 28(b) (mentioning as an anticompetitive effect "Increasing costs to produce consumer devices that comply with the Relevant Technology Standards, which manufacturers will likely pass through to consumers"); In the matter of Negotiated Data Solutions LLC (File No. 051 0094) FTC, Complaint of 23 September 2008, Docket No. C-4234, para. 37 (b) (alleged anti-competitive effects include "increases in price and/or reductions in the use or output of products that implement an IEEE standard enabling autonegotiation by or with 802.3 compliant products"). See also Motorola - Enforcement of GPRS standard essential patents (Case AT.39985) EC, decision C(2014) 2892 final of 29 April 2014, paras 377 and 387 (noting how certain disadvantageous provisions may ultimately raise prices of products).

${ }^{18}$ See e.g. In the matter of Motorola Mobility LLC, and Google Inc. (File No. 121 0120) FTC, Complaint of 24 July 2013, Docket No. C-4410, para. 28 (d) (mentioning as an alleged anticompetitive effect "Raising the costs of Google's competitors and thereby dampening competition between Google and makers of competing products, including, but not limited to, mobile phone operating systems, mobile phones, video compression technologies, and devices providing home internet access." $)$. 
ASCOLA 2016 - working paper, please ask before citing

implementation of a standard and in features of standard-compliant products). ${ }^{19}$

Moreover, hold-up and opportunism can more generally undermine willingness to

participate in and contribute to development of standards as well as implementation of standards. Therefore, leaving hold-up unremedied in antitrust and other areas of law can undermine achievement of innovation and other benefits of standard-setting cooperation. $^{20}$

${ }^{19}$ See e.g. In the matter of Motorola Mobility LLC, and Google Inc. (File No. 121 0120) FTC, Complaint of 24 July 2013, Docket No. C-4410, para. 3 ("This conduct will deter innovation by increasing the costs of manufacturing to a standard"); In the matter of Bosch (Robert Bosch GmbH) (File No. 121 0081) FTC, Statement of the FTC of 24 April 2013, p. 2 ("By threatening to exclude standard-compliant products from the marketplace, a SEP holder can demand and realize royalty payments that reflect the investments firms make to develop and implement the standard, rather than the economic value of the technology itself."). Concerns about follow-on innovation of disadvantageous licensing terms also appear to be included by more general concerns about hold-up deterring development and implementation of standards, as noted in the following footnote and the accompanying text.

${ }^{20}$ See e.g. Motorola - Enforcement of GPRS standard essential patents (Case AT.39985) EC, decision C(2014) 2892 final of 29 April 2014, paras 415-418 (e.g. noting at para. 415

"Motorola's seeking and enforcement of an injunction against Apple in Germany on the basis of its Cudak GPRS SEP may in addition undermine confidence in the standard-setting process and deprive consumers of its benefits."); In the matter of Motorola Mobility LLC, and Google Inc. (File No. 121 0120) FTC, Complaint of 24 July 2013, Docket No. C-4410, para. 28(c) (noting as an alleged anti-competitive effect "Undermining the integrity and efficiency of the standard-setting process and decreasing the incentives to participate in the process and adopt published standards") and para. 4 ("Left unchecked, such conduct may in the future cause or threaten to cause substantial injury to competition and to consumers."); In the matter of Negotiated Data Solutions LLC. (File No. 051 0094) FTC, Complaint of 23 September 2008, Docket No. C-4234, paras 37 (c)-(d) (listing as alleged anti-competitive effects "c. decreased incentives on the part of semiconductor chip and LAN equipment manufacturers to produce products that implement IEEE standards enabling autonegotiation by or with 802.3 compliant products; $d$. decreased incentives on the part of semiconductor chip and LAN equipment manufacturers and others to participate in IEEE or other standard setting activities; and e. both within and outside the semiconductor chip and LAN equipment industries decreased reliance, or willingness to rely, on standards established by industry standard setting organizations.”) 
ASCOLA 2016 - working paper, please ask before citing

These kinds of negative effect on innovation by attempted or potential hold-up or exploitation of market power by SEP holders are examples of anti-competitive effects invoked by the EC and FTC that are not based on exclusion from the relevant product or technology markets. Instead, innovation concerns stem from the risk of licensees being forced to accept onerous terms of licensing that prevent them from appropriately benefiting from their own innovations and the threat of hold-up undermining investment in the development and implementation of standards.

\subsection{Google specialized search allegations}

European and US investigations into alleged priority given to specialized Google services, use of content without prior consent in those services and the conditions under which content is used in services present another example of innovation concerns based on other than theories of anti-competitive foreclosure. While in these cases the concern that rival specialized search services are disadvantaged plays a significant role, the concerns extend beyond foreclosure of Google's specialized search rivals in various respects. As discussed below, the concerns are in part based on these practices, in a more limited manner, depriving other innovators of rewards and thus potentially harming their incentives to innovate and create. ${ }^{21}$

\footnotetext{
${ }^{21}$ Interestingly, allegations against similar practices based on claims of unlawful exclusionary conduct have not fared well. See e.g. Streetmap.EU Ltd v Google Inc. et al. [2016] EWHC 253 (Ch) [2016] All ER (D) 129 (Feb); Google et al. v Evermaps, Case No. 2009061231, Tribunal de Commerce de Paris (31 January 2012); Google Inc. et al. Case 408 HKO 36/13, Landgericht Hamburg, (4 April 2013). On the Google allegations and the concept of abuse under Art. 102 TFEU, see e.g. Andrea Renda, "Searching for harm or harming search? A look at the European Commission's antitrust investigation against Google" CEPS Special Report (2015) No. 118; Renato Nazzini, "Google and the (Ever-stretching) Boundaries of Article 102 TFUE” Journal of European Competition Law \& Practice (2015) Vol. 6 (5), 301 314.
} 
ASCOLA 2016 - working paper, please ask before citing

\subsubsection{Favorable treatment of Google's own specialized search services}

The FTC has investigated and the EC is investigating allegations that Google improperly gives priority to its own specialized search services. Since the FTC decided not to pursue those claims further, the focus will be on the concerns underpinning the still ongoing EC investigation. ${ }^{22}$

Concerns expressed by the EC regarding Google giving priority to its own specialized search services relate to rival specialized search services being improperly disadvantaged. However, these concerns also extend to Google potentially misleading customers by not informing them about the priority given to Google's own specialized search results, thus making more relevant search results less visible and less likely to be visited.

According to the EC

"Due to the favourable treatment of Google's own services, consumers are more likely to not make use of potentially more relevant

\footnotetext{
${ }^{22}$ By contrast, the FTC has decided to close its investigation into these concerns, citing in particular the difficulties of second guessing product design decisions that potentially offer consumer benefits. FTC, "Statement of the Federal Trade Commission Regarding Google's Search Practices In the Matter of Google Inc. File No. 111-0163" (Statement, 3 January 2013), available at <https://www.ftc.gov/system/files/documents/public_statements/295971/130103googlesearch stmtofcomm.pdf> accessed 17 June 2016 ("Challenging Google's product design decisions in this case would require the Commission - or a court - to second-guess a firm's product design decisions where plausible procompetitive justifications have been offered, and where those justifications are supported by ample evidence. Based on this evidence, we do not find Google's business practices with respect to the claimed search bias to be, on balance, demonstrably anticompetitive, and do not at this time have reason to believe that these practices violate Section 5.", 3). Moreover, the thrust of the FTC inquiry seems to have focused on whether the design was seeking to exclude rival potential competitive threats, that is, not necessarily concerns based on other than anti-competitive foreclosure ("A key issue for the Commission was to determine whether Google changed its search results primarily to exclude actual or potential competitors and inhibit the competitive process, or on the other hand, to improve the quality of its search product and the overall user experience."). Id., 2.
} 
ASCOLA 2016 - working paper, please ask before citing competing services. First, users are not aware of the promotion of Google's offer within the search results. Second, competitors' results that are potentially more relevant are less visible and even sometimes not directly visible to users - they are more difficult for the user to find, for instance because the user has to scroll down the screen to see them or has to go to a subsequent search results web page.

The Commission is concerned that this practice unduly diverts traffic away from Google's competitors in specialised search towards Google's own specialised search services. It therefore reduces the ability of consumers to find a potentially more relevant choice of specialised search services." (emphasis added) ${ }^{23}$

As an anti-competitive effect, this aspect of EC concerns would appear to be a direct consequence of exploiting market power to the detriment of consumers through reduction in quality of the service - not based on any foreclosure of, or disadvantage to, rivals. This would seem to reflect a duty to design the service in a transparent (nonmisleading) and objectively justifiable way that would allow consumers to optimally find potentially more relevant alternative rival services among the search results. ${ }^{24}$

\footnotetext{
${ }^{23} \mathrm{EC}$, "Commission seeks feedback on commitments offered by Google to address competition concerns - questions and answers" (MEMO/13/383, 25 April 2013). See also EC, "Antitrust: Commission obtains from Google comparable display of specialised search rivals - Frequently asked questions" (MEMO/14/87, 5 February 2014) ("Within its web search results, Google displays its own specialised search services more favourably than competing services. In many instances, relevant competing services are as a consequence more difficult for the user to find. Users are not informed of this favourable treatment of Google's own services.", emphasis added)

${ }^{24}$ This type of antitrust duty appears novel in EU law. See for possibilities of abuse consisting of failing to satisfy demand or adopt new technologies in the context of state-granted exclusive rights (Art. 106 TFEU) e.g. Case C-41/90 Klaus Höfner and Fritz Elser v Macrotron GmbH [1991] EU:C:1991:161; Case C-179/90 Merci convenzionali porto di
} Genova SpA v Siderurgica Gabrielli SpA [1991] EU:C:1991:464. 
ASCOLA 2016 - working paper, please ask before citing

In addition to this immediate negative consumer welfare effect of allegedly suboptimal service design, the EC is concerned about traffic being unduly diverted from rival specialized search services and its impact on competitors' incentives to innovate in specialized search services:

"Since Google is an important source of traffic for competing specialised search services, this may reduce competitors' incentives to innovate in specialised search." (emphasis added $)^{25}$

Later, in relation to a statement of objections issued regarding shopping comparison results, the European Commission similarly stated:

"Google's conduct has a negative impact on consumers and innovation. It means that users do not necessarily see the most relevant comparison shopping results in response to their queries, and that incentives to innovate from rivals are lowered as they know that however good their product, they will not benefit from the same prominence as Google's product." (emphasis added) ${ }^{26}$

These concerns are not limited to conventional foreclosure concerns. First, it does not seem that the concern would be that rivals were actually or potentially excluded from the market, or that hindering rivals' ability to compete would result in competitive harm. Rather, the concerns are limited to reduction of incentives to innovate in specialized search services, not anti-competitive effects resulting from market foreclosure or reduction of rivalry caused by the conduct.

Second, the concerns may not be limited to disadvantages caused by the conduct to rival specialized search services. For instance, to the extent they may illustrate the

\footnotetext{
${ }^{25}$ EC, "Commission seeks feedback on commitments offered by Google to address competition concerns - questions and answers" (MEMO/13/383, 25 April 2013). ${ }^{26}$ EC, "Antitrust: Commission sends Statement of Objections to Google on comparison shopping service" (Fact Sheet MEMO/15/4781, 15 April 2015).
} 
ASCOLA 2016 - working paper, please ask before citing

concerns of the EC, commitments earlier offered by Google to address EC concerns appeared to an extent also to safeguard websites (from which traffic was otherwise "unduly" diverted) that cannot necessarily be deemed to be specialized search services (or the concept is understood very broadly to cover almost any website with search facilities) or as Google's actual or potential competitors in an antitrust sense.

To illustrate, in 2013 Google offered to address concerns in the following way:

"To address these concerns, Google offers for a period of 5 years to:

(i) - label promoted links to its own specialised search services so that users can distinguish them from natural web search results,

- clearly separate these promoted links from other web search results by clear graphical features (such as a frame), and - display links to three rival specialised search services close to its own services, in a place that is clearly visible to users" (emphasis added $)^{27}$

Moreover, according to the European Commission, in relation to commitments offered by Google in 2014:

"In its proposal, Google has now accepted to guarantee that whenever it promotes its own specialised search services on its web page (e.g. for products, hotels, restaurants, etc.), the services of three rivals, selected through an objective method, will also be displayed in a way that is clearly visible to users and comparable to the way in which Google displays its own services (see also MEMO/14/87). This principle will apply not only for existing specialised search services,

\footnotetext{
${ }^{27}$ EC, "Antitrust: Commission seeks feedback on commitments offered by Google to address competition concerns" (Press release IP/13/371, 25 April 2013).
} 
ASCOLA 2016 - working paper, please ask before citing

but also to changes in the presentation of those services and for future services." (emphasis added) ${ }^{28}$

And as to the commitments offered in 2014 according to the European Commission:

"To address this concern, Google proposes to implement a threefold remedy for all its current and future specialised search services and for all search entry points (i.e. irrespective of how the search query is made).

- Users will be informed by a label of the fact that Google's own specialised search services are promoted.

- These services will be graphically separated from other search results, so the distinction with normal web search results will be clear.

- For relevant specialised search services, Google will display prominent links to three rival specialised search services in a format which is visually comparable to that of links to its own services. For instance, if the Google links have images, the rival links will have images as well, including on mobile devices." $(\text { emphasis added })^{29}$

Finally, as to remedies sought by the EC for shopping comparison (a category of specialized search) in 2015:

"The Statement of Objections takes the preliminary view that in order to remedy the conduct, Google should treat its own comparison

\footnotetext{
${ }^{28}$ EC, "Antitrust: Commission obtains from Google comparable display of specialised search rivals" (Press release IP/14/116, 5 February 2014).

${ }^{29}$ EC, "Antitrust: Commission obtains from Google comparable display of specialised search rivals - Frequently asked questions” (MEMO/14/87, 5 February 2014).
} 
ASCOLA 2016 - working paper, please ask before citing

shopping service and those of rivals in the same way. This would not interfere with either the algorithms Google applies or how it designs its search results pages. It would, however, mean that when Google shows comparison shopping services in response to a user's query, the most relevant service or services would be selected to appear in Google's search results pages." ${ }^{30}$

While the commitments previously proposed by Google and remedies now envisaged by EC are primarily designed for the benefit of rival specialized search services, they also seem to benefit other kinds of website by providing safeguards against undue traffic diversion from a much broader class of websites. In particular, the proposed labeling and graphic separation remedies would seem to have protected all kinds of website by addressing the concern that users are not aware of promotion by Google of its own services and thus are less likely to visit those sites. By addressing that risk of unawareness among users of the prioritization of Google specialized search results, various kinds of website similarly could have benefited by the proposed commitments. ${ }^{31}$

\subsubsection{Use of content without prior authorization (scraping)}

Both the EC and a group of FTC commissioners have expressed concerns about Google's use of content of specialized search services without consent. The EC is still

\footnotetext{
${ }^{30} \mathrm{EC}$, "Antitrust: Commission sends Statement of Objections to Google on comparison shopping service" (Fact Sheet MEMO/15/4781, 15 April 2015).

${ }^{31}$ Moreover, the commitment proposed by Google to display links in search results to three rival specialized search services and the remedy sought by EC to ban preferential treatment of Google's own shopping comparison (see above) could in practice also safeguard websites other than Google's specialized search rivals, understood in an antitrust sense. However, it is difficult on the basis of publicly available information to evaluate what those commitments and remedies legally and technically specifically entail.
} 
ASCOLA 2016 - working paper, please ask before citing

investigating this concern, ${ }^{32}$ whereas the U.S. FTC closed its investigation following Google committing to certain changes in its practices. ${ }^{33}$ Also the Italian competition authority has settled similar concerns by means of a commitment decision. ${ }^{34}$

Competition concerns about use of content without prior consent are largely based on the theory that if content from third party websites is shown in Google's (specialized) search service results, traffic to other websites from which the content originates is reduced. This could reduce the incentives of other websites to invest in creation of content and innovation in their services.

The EC characterizes the scraping conduct investigated in the following manner:

${ }^{32}$ EC, "Antitrust: Commission sends Statement of Objections to Google on comparison
shopping service" (Fact Sheet MEMO/15/4781, 15 April 2015). See text below for the concerns expressed by the European Commission with regard to scraping. Several complaints have reportedly been filed in this respect. See e.g. Getty Images, "Getty Images to file competition law complaint against Google" available at <http://press.gettyimages.com/gettyimages-files-competition-law-complaint-against-google/> accessed 17 June 2016; Stephanie Bodoni and Aoife White, "News Corp. Adds to Google Antitrust Woes on Android, Search" (Bloomberg, 18 April 2016), available at http://www.bloomberg.com/news/articles/2016-0418/news-corp-adds-to-google-s-antitrust-woes-over-android-search accessed 15 September 2016; Center of the Picture Industry, "CEPIC submits EU antitrust complaint against Google Images" (CEPIC, 14 November 2013), available at <http://cepic.org/issues/cepic-submits-euantitrust-complaint-against-google-images $>$ accessed 15 September 2016.

${ }^{33}$ FTC, "Statement of the Federal Trade Commission Regarding Google's Search Practices In the Matter of Google Inc. File No. 111-0163" (Statement, 3 January 2013), available at <https://www.ftc.gov/system/files/documents/public_statements/295971/130103googlesearch stmtofcomm.pdf> accessed 17 June 2016; David Drummond, on behalf of Google Inc., Letter of Commitment to the FTC in the case Google Inc. (27 December 2012), available at <https://www.ftc.gov/system/files/documents/closing_letters/googleinc./130103googleletterchairmanleibowitz.pdf> accessed 17 June 2016.

${ }^{34}$ Italian Competition Authority (Autorità Garante della Concorrenza e del Mercato), "Antitrust authority accepts Google commitments and implores Parliament to update copyright laws" (Press Release A420 - AS787, 17 January 2010). 
ASCOLA 2016 - working paper, please ask before citing

"The second competition concern relates to the way Google uses without consent content from competing specialised search services in its own offerings.

Google uses on its own specialised search services original material taken from the websites of its competitors, such as for instance user reviews. Google thereby benefits from the investments of competitors, sometimes against their explicit will. Competitors who have objected to the use of their information in Google's specialised search services have been told that the only way for their information not to appear in Google's specialised search service would be to opt out of Google's services, including Google's web search, which is not a sustainable business option for most web sites." (emphasis added) ${ }^{35}$

The European Commission expressed the following concerns with respect to the conduct:

\begin{abstract}
"The Commission is concerned that the practice of using third party content to promote Google's own services may reduce competitors' incentives to invest in the creation of original content for the benefit of internet users. Indeed, if users know that Google's specialised search services contain all the relevant information that is posted on the web, their incentives to visit other sites which contain only a part
\end{abstract}

\footnotetext{
${ }^{35} \mathrm{EC}$, "Commission seeks feedback on commitments offered by Google to address competition concerns - questions and answers" (MEMO/13/383, 25 April 2013). See similarly EC, "Antitrust: Commission obtains from Google comparable display of specialised search rivals - Frequently asked questions" (MEMO/14/87, 5 February 2014) ("The second concern relates to the way Google uses content from competing specialised search services in its own offerings. Google uses on its own specialised search sites material such as user reviews from the websites of its competitors, thereby benefiting from the investments of competitors without their prior authorisation - and sometimes even against their explicit will. The Commission has not expressed a concern about the appropriate remuneration for copyright-protected material.”)
} 
ASCOLA 2016 - working paper, please ask before citing

of that information will be significantly reduced, even if these were the sites from which that information originates." (emphasis added) $)^{36}$

Moreover, the European Commission justified the need for an antitrust investigation as follows:
"If Google's market position in web search gives it the ability to copy and use all relevant information available on the web on its own specialised search services, users may no longer have incentives to visit competing services. Competitors of Google may lose the incentive to innovate or invest in the generation of original content. This competition concern arises whether or not the information copied and used by Google is covered by IP rights." (emphasis added $)^{37}$

Three FTC commissioners also expressed strong concerns about the conduct and its potential negative effects on other websites' incentives to innovate:
"The Commission also investigated allegations that Google had unfairly "scraped," or misappropriated, the content of certain competing websites, passed this content off as its own, and then threatened to delist these rivals entirely from Google's search results when they protested the misappropriation of their content. The Commission considered whether this conduct could have diminished the incentive of Google's rivals to invest in bringing new and innovative content and services to the Internet in the future or reduced Google's own incentive to innovate in the relevant markets, and if so whether this conduct was actionable as an unfair method of

\footnotetext{
${ }^{36} \mathrm{EC}$, "Commission seeks feedback on commitments offered by Google to address competition concerns - questions and answers" (MEMO/13/383, 25 April 2013).

${ }^{37} \mathrm{EC}$, "Commission seeks feedback on commitments offered by Google to address competition concerns - questions and answers" (MEMO/13/383, 25 April 2013).
} 
ASCOLA 2016 - working paper, please ask before citing

competition within the meaning of Section 5 of the FTC Act, 15

U.S.C. § 45. Chairman Leibowitz, Commissioner Brill and

Commissioner Ramirez found the record evidence to support strong

concerns about Google's conduct in this regard, and Google has

committed to refrain from this conduct in the future." (emphasis

added $)^{38}$

As with regard to traffic diversion concerns, while the focus of these concerns is on detrimental effects on rival specialized search services, here too concerns do not appear to be based on complete or significant foreclosure of Google's rivals from the market, or the effects of such exclusion on innovation. Instead, the concerns appear to be limited to reduction of incentives to invest in content creation and to innovate by other specialized search services resulting from diversion of traffic caused by direct presentation of content in Google's search results.

As in the case of self-prioritization concerns discussed above, the scraping concern also seems to extend beyond harming innovation incentives of rivals to Google's specialized search services. Many kinds of website, not necessarily only those that can be characterized as specialized search services or as actual or potential competitors of Google, would appear to be sought to be safeguarded. Judging by the commitments offered by Google to the EC and FTC, the enforcers' concerns appear to go beyond incentives of rival specialized search services. For example, Google's commitments that the U.S. FTC deemed sufficient to close its investigation into scraping concerns and the commitments Google offered to the $\mathrm{EC}$ would allow various kinds of website (not only rival specialized search services) to designate to what extent and how their content can be used in Google specialized search services. ${ }^{39}$

\footnotetext{
${ }^{38}$ FTC, "Statement of the Federal Trade Commission Regarding Google's Search Practices In the Matter of Google Inc. File No. 111-0163” (Statement, 3 January 2013), footnote 2.

${ }^{39}$ See also Italian Competition Authority (Autorità Garante della Concorrenza e del Mercato), "Antitrust authority accepts Google commitments and implores Parliament to update copyright laws" (Press Release A420 - AS787, 17 January 2010) (accepting commitments
} 
ASCOLA 2016 - working paper, please ask before citing

For instance, according to the commitments offered by Google in 2013 to the EC, Google would:

"(ii) - offer all websites the option to opt-out from the use of all their content in Google's specialised search services, while ensuring that any opt-out does not unduly affect the ranking of those web sites in Google's general web search results,

- offer all specialised search web sites that focus on product search or local search the option to mark certain categories of information in such a way that such information is not indexed or used by Google, - provide newspaper publishers with a mechanism allowing them to control on a web page per web page basis the display of their content in Google News" (emphasis added) ${ }^{40}$

Similarly, the EC explained commitments offered in 2014 as follows:

"To address this concern, Google proposes to allow third parties to opt out from the use of their content in Google's specialised search services without undue impact on their ranking in Google's general search results or on their ranking in Google's AdWords programme. A general opt-out will be open to all web sites, on a subdomain by subdomain basis. A more specific opt-out with finer granularity and more control over content will be accessible to news publishers only, for the control of the use of their content in Google News" (emphasis added $)^{41}$

allowing publishers to selectively opt-out from Google News without penalization in general Google search).

${ }^{40}$ European Commission, “Antitrust: Commission seeks feedback on commitments offered by Google to address competition concerns” (Press release IP/13/371, 25 April 2013).

${ }^{41}$ European Commission, “Antitrust: Commission obtains from Google comparable display of specialised search rivals - Frequently asked questions" (MEMO/14/87, 5 February 2014). 
ASCOLA 2016 - working paper, please ask before citing

Google also made a similar but more limited commitment to the FTC:

"Within 90 days, Google will make available a web-based notice form that provides website owners with the option to opt out from display on Google's Covered Webpages of content from their website that has been crawled by Google. When a website owner exercises this option, Google will cease displaying crawled content from the domain name designated by the website owner on Covered Webpages on the google.com domain in the United States. Website owners will be able to exercise the opt-out described above by completing a web-based notice form. Google will implement the opt-out within 30 business days of receiving a properly completed notice form." (footnotes omitted and emphasis added $)^{42}$

Thus, although the competition concerns expressed by the EC and three FTC commissioners highlight the potential detrimental effects of scraping on innovation incentives of special search rivals of Google, the commitments offered and accepted appear to address concerns about incentives of a significantly broader set of firms (all websites, all specialized search websites and newspaper publishers) to create and innovate, regardless of the nature of their activities and competitive relationship to Google.

\subsection{3. $\quad$ Terms concerning use of content in specialized search services}

Allegations about unfairness of the conditions under which content from other websites can be used particularly in the Google News service have been examined by

\footnotetext{
42 David Drummond, on behalf of Google Inc., Letter of Commitment to the FTC in the case Google Inc. (27 December 2012), available at <https://www.ftc.gov/system/files/documents/closing_letters/googleinc./130103googleletterchairmanleibowitz.pdf > accessed 17 June 2016.
} 
ASCOLA 2016 - working paper, please ask before citing

national courts and authorities in the EU. ${ }^{43}$ The EC has stated that its scraping concerns do not extend to this question, ${ }^{44}$ which differs from scraping concerns (see above Section 3.2.2.) in that here the concern is not the use of content without consent, but the terms that websites need to accept in order to appear fully or at all in Google News results (or in order otherwise to avoid penalization in Google's search services). ${ }^{45}$

\footnotetext{
${ }^{43}$ In the US, there appear not to have been antitrust investigations or private antitrust suits based solely on the unfair nature of licensing terms for creators of content. However, allegations about the unfairness of certain practices of Amazon have been made to the
} Department of Justice, Antitrust Division by a group of authors. Roxana Robinson, "A Call to Investigate Amazon" (The Authors Guild, 13 July 2015), available at <https://www.authorsguild.org/industry-advocacy/a-call-to-investigate-amazon/> accessed 15 September 2016.

${ }^{44} \mathrm{EC}$, "Commission seeks feedback on commitments offered by Google to address competition concerns - questions and answers" (MEMO/13/383, 25 April 2013) ("The Commission's concerns cover the fact that Google uses original third party information on its specialised search results services without prior authorisation, including the information of newspaper publishers. But they do not cover monetary considerations in this respect. The Commission considers that the issue of payment of third party content is more directly tied to Intellectual Property law.") However, the EC is considering whether other action to ensure fair allocation of value should be safeguarded as one of its initiatives concerning the Digital Single Market. Communication from the EC of 9 December 2015, Towards a modern, more European copyright framework, $\operatorname{COM}(2015) 626$ final. The EC has recently proposed that authors and performers be given protection in contractual relationships. European Commission, "Proposal for a Directive of the European Parliament and of the Council on copyright in the Digital Single Market" (COM(2016)593 FINAL, 14 September 2016).

${ }^{45}$ Nevertheless, complaints claiming that the terms are unfair have reportedly been lodged before the EC. See e.g. Verband Deutscher Zeitschriftenverleger, "Verlegerverbände bündeln "Google-Beschwerden" in Brüssel" (VDZ, 27 February 2012) available at <http://www.vdz.de/medienpolitik-singlenews/news/verlegerverbaende-buendeln-googlebeschwerden-in-bruessel/> accessed 15 September 2016; Independent Music Companies Association, "Dispute Between YouTube and Independent Music Companies - Formal Process Starts in Brussels" (IMPALA, 27 June 2014), available at <http://www.impalamusic.org/content/dispute-between-youtube-and-independent-musiccompanies-\%E2\%80\%93-formal-process-starts-brussels $>$ accessed 15 September 2016. 
ASCOLA 2016 - working paper, please ask before citing

Allegations about abusive unfairness of the conditions that full visibility of snippets of text and preview photos in Google News require acceptance of their royalty-free use (or failing acceptance, limited visibility) have been addressed by the German Competition Authority (Bundeskartellamt, "GCA") and the Berlin regional court (LG Berlin). Both dismissed the allegation that the requirement of acquiescing to royaltyfree use was abusive due to being unfair (excessively low). The GCA considered that avoidance of risk of infringing neighboring rights provided under German law in any event would constitute an objective justification for alleged unfairness of the terms. ${ }^{46}$ LG Berlin reasoned that a finding of abuse could not be justified because other than royalty-free terms would upset the mutually beneficial balance between news publishers, Google, and consumers. ${ }^{47}$

These concerns as to the conditions under which content from a third party website is displayed on Google News are essentially about the fairness of rewards for creators of content. However, there is little discussion in the decisions as to whether the practices could harm rewards of news publishers (apart from recognizing that search services

\footnotetext{
${ }^{46}$ Google/VG Media et al. (Case B6-126/14) German Competition Authority (GCA), decision of 8 September 2015, paras 221-225. The GCA also questioned whether Google required royalty-free use explicitly or in practice. See paras 218-220. Moreover, according to the GCA an abuse based on refusal to agree to compensation for use of related rights was also highly unlikely, as no duty to deal in that manner could be assumed. See paras 209-217. Also abusive discrimination of publishers who did not consent to royalty-free use was unlikely given the legitimate interest in avoiding the risk of infringing neighboring rights. See paras 186-208.

${ }^{47}$ Google Inc. Case 92 O 5/14 Kart, Landgericht Berlin, (19 February 2016), 16. Nor was there unjustified discrimination. Id., 10-16. Relatedly, the Italian competition authority, in the commitment decision mentioned above, ensured that Google is more transparent as to what share of advertising income websites are entitled to and that websites can independently monitor use of their site affecting advertising revenues. This would appear to address fairness in the sense of foreseeability and monitoring. Italian Competition Authority (Autorità Garante della Concorrenza e del Mercato), “Antitrust authority accepts Google commitments and implores Parliament to update copyright laws" (Press Release A420 - AS787, 17 January 2010).
} 
ASCOLA 2016 - working paper, please ask before citing

also provide benefits to news publishers) or ultimately their incentives to create content. $^{48}$

\section{Standards for antitrust condemnation of non-exclusionary innovation restraints}

The EC and FTC investigations discussed above illustrate antitrust concerns in essence based on conduct depriving other innovators of rewards and thus potentially harming their incentives to innovate. In the case of SEP enforcement and licensing, innovation could be threatened by exploitation of market and/or hold-up power to impose disadvantageous licensing terms. As regards Google's specialized search services, incentives of other websites could be threatened by reduced traffic and no or low compensation for use of content.

These concerns about unilateral conduct lowering rewards for innovation are not usual for antitrust to the extent they exhibit market failures such as public goods (e.g. freeriding on others' innovations) or transaction costs (e.g. risks of hold-up to investment). This unusual nature of competitive harm prompts the question whether alleged negative effects on innovation based on such mechanisms can form a basis for an antitrust infringement as well as what standards should be applied to judge them. Below, these challenges of identifying unilateral non-exclusionary practices warranting antitrust condemnation are discussed.

\subsection{Anti-competitive effect based on a non-exclusionary theory of innovation harm}

\footnotetext{
${ }^{48}$ The issue itself could in the EU be relegated to copyright law following a proposal by the EC to give publishers a neighboring right to press publications and otherwise give safeguards to copyright holders in contracting. European Commission, "Proposal for a Directive of the European Parliament and of the Council on copyright in the Digital Single Market"
} (COM(2016)593 FINAL, 14 September 2016). 
ASCOLA 2016 - working paper, please ask before citing

\subsubsection{Nature of non-exclusionary effects on innovation as anti-competitive} $\underline{\text { harm }}$

A common feature of theories of innovation harm discussed above is that they exhibit a concern that the conduct of a dominant firm threatens the rewards of other innovators and thereby ultimately incentives to innovate in the market. No conventional exclusionary conduct involving anti-competitive foreclosure might be present (see Section 3 above) and concern about unfairness is not about static welfare or distributive effects (e.g. deadweight loss or transfer of consumer welfare to producers). Instead, the concerns examined are based on the premise that the expected rewards of other innovators may be reduced, to the detriment of incentives to innovate in the market.

In this sense of non-exclusionary theories of harm based on innovation being harmed by their nature fit the mission of antitrust to protect the effective functioning of markets (in the dimension of innovation) in the interest of ultimately promoting consumer welfare. However, not all inefficiencies in the market render associated conduct anti-competitive, as antitrust is primarily concerned with the negative effects of market power.

Nevertheless, when claimed harmful effects on innovation are based on exploitation of market power, non-exclusionary effects on innovation can be similar in nature, origin and outcome as in established types of antitrust violation. ${ }^{49}$ In this respect, both in the case of SEP licensing practices and search practices, the concerns of the EC and FTC seem not to be based on hold-up or free-riding on its own, but the market power of firms that could be exercised in ways that harm the functioning of the markets in terms of producing innovation due to disincentives caused by hold-up and free-riding. It is

\footnotetext{
${ }^{49}$ By contrast, were unilateral conduct undesirable for innovation solely on the grounds of market failures other than market power (such as externalities, transaction costs or information asymmetries) it would be difficult to justify the use of antitrust to address innovation concerns raised by such conduct.
} 
ASCOLA 2016 - working paper, please ask before citing

thus not solely hold-up or misappropriation that is questioned but exercise of market power potentially involving them. ${ }^{50}$

Moreover, the mechanisms by which markets are claimed to operate inefficiently and ultimately to result in harm to consumer welfare are similar as in the case of established types of antitrust infringement. Theories of non-exclusionary innovation harm share elements with both exclusionary conduct (e.g. exclusionary abuses and monopolization) distorting the functioning of the market by reducing rivalry and with otherwise unlawful unilateral conduct (e.g. exploiting market power in EU antitrust and stand-alone unfair methods of competition in the US) involving exploitation of market power more directly harming economic welfare. To the extent, for instance, EU antitrust law condemns exploitative abuses on the basis of static welfare effects (e.g. excessive prices), it would a fortiori be justified to condemn practices exploiting market power that harms innovation, as the latter type of effects can be more detrimental to consumer welfare and economic growth than mere static welfare losses. ${ }^{51}$

${ }^{50}$ For instance, the EC investigation in scraping seems to be premised on the market position of Google enabling the potentially problematic conduct - not scraping conduct as such. EC, "Commission seeks feedback on commitments offered by Google to address competition concerns - questions and answers" (MEMO/13/383, 25 April 2013). ("If Google's market position in web search gives it the ability to copy and use all relevant information available on the web on its own specialised search services, users may no longer have incentives to visit competing services.", emphasis added).

${ }^{51}$ As discussed above, in many of the cases examined, alleged or suspected anti-competitive effects involve both non-exclusionary and exclusionary aspects. The exclusionary aspects could bring non-exclusionary aspects to familiar antitrust ground. Interestingly, some recent allegations seem to be based on an allegation that dominance is maintained or enhanced by improper means (by using content without authorization), but without necessarily involving the conduct contested excluding rivals from the market. See e.g. Getty Images, "Getty Images to file competition law complaint against Google" available at <http://press.gettyimages.com/getty-images-files-competition-law-complaint-againstgoogle/> accessed 17 June 2016; Stephanie Bodoni and Aoife White, "News Corp. Adds to Google Antitrust Woes on Android, Search" (Bloomberg, 18 April 2016), available at http://www.bloomberg.com/news/articles/2016-04-18/news-corp-adds-to-google-s-antitrust-

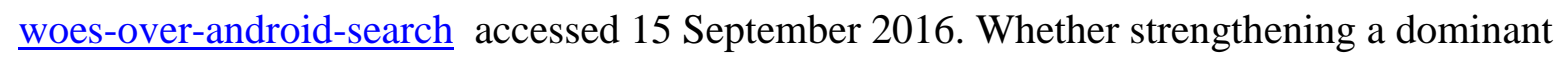


ASCOLA 2016 - working paper, please ask before citing

\subsection{2. $\quad$ Likelihood of anti-competitive harm to innovation}

A challenge with the non-exclusionary innovation harm theories examined in this article is that negative effects on innovation are theoretically and empirically highly ambiguous and thus only likely to be borne out by specific circumstances. ${ }^{52}$ To begin with, it is not obvious whether the above-examined practices are likely to reduce expected rewards of other innovators overall as the conduct may also enhance their rewards (e.g. by increasing web traffic) so that the net effect is ambiguous. Further, negative effects on rewards of other innovators do not necessarily equate with reduced incentives to innovate on the market. For instance, if a dominant firm is an important source of innovation or if in any event effective rivalry in innovation remains despite some innovators being disadvantaged, no market-wide harm to innovation might result.

Interestingly, some of the concerns about innovation being harmed by the practices examined in this article are causally distant from conduct and to a significant degree have to do with the general prevailing legal and economic conditions for innovation. For instance, concerns that opportunism in SEP licensing threatens investment in standardization may stem more from the general risk of hold-up (e.g. enabled and not deterred under other laws) than from the actual conduct of an SEP holder. ${ }^{53}$ Similarly, in the case of the search allegations, it can be argued that reduced rewards are caused by changes in the communications technology that enhance competition between creators of content, lower costs of free-riding and alter existing business models. ${ }^{54}$ In the cases both of such SEP and scraping concerns, it may be questioned to what extent the cause of alleged sub-optimal incentives for investment and innovation can be

position based on practices other than exclusion of rivals could form the basis for an infringement is, however, beyond the scope of this paper.

${ }^{52}$ Arguably, at least these concerns are more ambiguous than in the case of conventional anticompetitive foreclosure prohibited as exclusionary conduct.

${ }^{53}$ See above Section 3.1.2.

${ }^{54}$ See above Section 3.2.2. 
ASCOLA 2016 - working paper, please ask before citing

found, for instance, within IP law that may allow injunctive relief for SEP

infringements in problematic situations and not providing sufficient protection against some scraping practices, instead of being caused by the conduct. ${ }^{55}$ For instance, it may be problematic to establish that conduct of an SEP holder would causally harm standards-development in organizations or sectors other than those where the SEP holder is active.

\subsection{Pro-competitive aspects of conduct as justifications}

Another challenge with the allegations examined relating to SEPs and specialized search is that the practices are capable of promoting innovation and consumer welfare. First, innovation in the design of specialized search services can provide immediate benefits to their users, such as by directly enhancing the quality of the service to users. For example, quicker and more conveniently presented search results can save consumers time and effort.

Second, the conduct may be a means to be rewarded from innovation and thereby form a basis for a firm's incentives to innovate. For instance, SEP holders' incentives to innovate crucially depend on their ability to conclude licensing agreements compliant with their licensing commitments (e.g. FRAND), which can be difficult without the possibility of obtaining injunctive relief in case would-be licensees do not accept these licensing demands. Similarly, competitive advantages and commercial value provided by service design that attracts users underlies investments to innovate in such services. The practices examined in this paper could, therefore, remain overall desirable to innovation and consumer welfare to the extent they can be justified by such immediate or indirect innovation-related benefits. However, that does not mean that the practices are always justified from an antitrust policy point of view. In particular, while the practices are capable of producing such innovation benefits, conduct that goes further

\footnotetext{
${ }^{55}$ However, as discussed above in Section 4.1.1., when concerns are attributable to the exploitation of market power, it may be the conduct, not merely the presence of market failures, that gives rise to anti-competitive effects.
} 
ASCOLA 2016 - working paper, please ask before citing

than necessary to attain such benefits may lack justification. ${ }^{56}$ For instance, while SEP holders are generally entitled to seek terms of licensing that comply with the licensing commitments they have made ${ }^{57}$ conduct by SEP holders to refuse licenses on committed terms and attempts to seek higher rewards may render conduct unjustifiable. ${ }^{58}$ Both the EC and FTC thus acknowledge these rights and legitimate interests of SEP holders, while questioning injunctive relief and licensing demands that are not in line with the licensing commitments the SEP itself has voluntarily given as a precondition for its technology to be incorporated into a standard.

Similarly, the design of a specialized search service that harms innovation by others in a way that is disproportionate or unjustified in view of immediate or indirect benefits to consumers could be rendered unjustified. In this regard, concerns expressed by the EC may suggest a more stringent standard of a dominant firm being required to design services in a way that is not less desirable for consumers than justified, ${ }^{59}$ whereas the

${ }^{56}$ Under Art 102 TFEU and $§ 5$ FTC Act, these desirable aspects may avoid triggering potential antitrust liability in the first place (e.g. prevent characterization as a UMC or abuse) or can justify prima facie infringing conduct on the basis of the pro-competitive benefits it produces or other arguments applicable in the US or EU (e.g. as forming a privileged exercise of IPRs, being objectively justified or constituting reasonable protection of legitimate interests).

${ }^{57}$ See for conditions under which an SEP holder avoids committing an abuse in the EU while seeking injunctive remedies C-170/13 Huawei Technologies [2015] EU:C:2015:477.

${ }^{58}$ See e.g. Motorola - Enforcement of GPRS standard essential patents (Case AT.39985) EC, decision C(2014) 2892 final of 29 April 2014; In the matter of Motorola Mobility LLC, and Google Inc. (File No. 121 0120) FTC, Docket No. C-4410. See also Margrethe Vestager, EU Competition Commissioner, "How competition supports innovation" (Speech at the Regulation4Innovation Conference, Brussels, 24 May 2016), available at <https://ec.europa.eu/commission/2014-2019/vestager/announcements/how-competitionsupports-innovation_en> accessed 17 June 2016 (noting that SEP holders are not prevented from seeking fair rewards, but cannot refuse licenses to those willing to pay a fair price for the use of patents).

${ }^{59}$ See e.g. EC, "Commission seeks feedback on commitments offered by Google to address competition concerns - questions and answers" (MEMO/13/383, 25 April 2013). 
ASCOLA 2016 - working paper, please ask before citing

FTC has indicated that it is not willing to second-guess product design choices that have plausible pro-competitive benefits. ${ }^{60}$

\subsection{Standards for condemning practices on the basis of their alleged non- exclusionary innovation effects}

The uncertainty about non-exclusionary anti-competitive effects on innovation and the presence of redeeming and pro-competitive aspects of the practices examined warrants greater caution than in the case of many established types of unilateral antitrust infringement, as discussed above. To avoid undermining innovation in antitrust enforcement in individual cases and promulgation of generally applicable antitrust standards, it would be warranted to require a likelihood and magnitude of alleged anticompetitive effects that in view of the pro-competitive aspects of the conduct justify the risks associated with deterring wholly benign (no anti-competitive effects) and overall pro-competitive practices. The strongest case for finding infringement on the basis of alleged non-exclusionary anti-competitive effects would be when conduct deemed likely to harm innovation lacks any pro-competitive aspects or is disproportionate for attaining pro-competitive benefits. ${ }^{61}$ In these situations, such

${ }^{60}$ FTC, "Statement of the Federal Trade Commission Regarding Google's Search Practices In the Matter of Google Inc. File No. 111-0163” (Statement, 3 January 2013), available at <https://www.ftc.gov/system/files/documents/public_statements/295971/130103googlesearch stmtofcomm.pdf $>$ accessed 17 June 2016.

${ }^{61}$ This would appear to be in line with the approach of the US FTC and characterizations of the general concept of abuse by the CJEU. See FTC, "Statement of Enforcement Principles Regarding 'Unfair Methods of Competition' Under Section 5 of the Federal Trade Commission Act”' (Commission policy statement), Federal Register Vol. 80, No. 182, p. 57056 [2015] (anti-competitive effects and pro-competitive justifications); Case C-52/09 Konkurrensverket v TeliaSonera Sverige AB [2011] ECLI:EU:C:2011:83 (requisite need for anti-competitive effects); Case C-209/10 Post Danmark A/S v Konkurrencerådet [2012] ECLI:EU:C:2012:172 (efficiency justifications). However, it is not clear if in the case of purely exploitative abuses actual or potential anti-competitive effects need to be established, as in such cases the CJEU has focused on whether conduct is proportional to legitimate aims 
ASCOLA 2016 - working paper, please ask before citing

conduct could in principle be condemned while leaving undeterred less harmful practices capable of producing similar pro-competitive aspects. When conduct is reasonable with a view to attaining pro-competitive benefits, antitrust might be better off avoiding condemnation unless it is confident that the anti-competitive effects of the conduct on innovation outweigh the pro-competitive aspects. To summarize, where conduct (1) is likely to produce anti-competitive effects and either (2(a)) is not reasonably necessary to attain pro-competitive benefits or (2(b)) its anti-competitive effects clearly outweigh its pro-competitive effects, antitrust condemnation can safeguard innovation in markets to the ultimate benefit of consumer welfare.

\section{Conclusions}

Several cases in which the EC and the FTC have recently intervened in unilateral conduct entail allegations of innovation being anti-competitively harmed on the basis of theories of harm other than anti-competitive foreclosure. Instead of rivals being excluded from the market, alleged or suspected anti-competitive harm to innovation in these cases is based on a dominant firm improperly depriving other innovators of appropriate rewards (e.g. by unduly diverting web traffic from innovators or by imposing disadvantageous licensing terms on innovators).

To the extent that these negative effects on innovation result from the exercise of market power, they could be characterized as anti-competitive effects that can form the

or economic value, not the effects of conduct. See e.g. Case C-52/07 Kanal 5 Ltd and TV 4 AB v Föreningen Svenska Tonsättares Internationella Musikbyrå (STIM) upa. [2008] EU:C:2008:703; Case 127/73 Belgische Radio en Televisie and société belge des auteurs, compositeurs et éditeurs v SV SABAM and NV Fonior [1974] EU:C:1974:25. For instance, in the FTC interventions examined above, the FTC claimed there was no legitimate efficiency justification for the conduct. See e.g. In the matter of Motorola Mobility LLC, and Google Inc. (File No. 121 0120) FTC, Complaint of 24 July 2013, Docket No. C-4410, para. 29 ("There is no legitimate efficiency justification sufficient to outweigh the harm to competition and consumers threatened by Google's conduct."). Similarly, the EC rejected objective justifications argued in Motorola - Enforcement of GPRS standard essential patents (Case AT.39985) EC, decision C(2014) 2892 final of 29 April 2014, paras 412-491. 
ASCOLA 2016 - working paper, please ask before citing

basis for an antitrust infringement. However, theories of depressed rewards are subject to considerable theoretical and empirical uncertainty, subjecting them to a heightened risk of erroneous deterrence. The practices examined also possess innovation related redeeming aspects that up to a point can justify conduct as not overall harmful to innovation. In order for antitrust to avoid erroneously deterring conduct that does not overall harm innovation and consumer welfare, alleged anti-competitive effects based on non-exclusionary theories of harm should be established as likely and conduct either as not reasonably necessary for attaining redeeming or pro-competitive benefits or as unlikely to produce pro-competitive benefits that outweigh the anti-competitive effects. 